\title{
Beyond the Empirical Turn: Elements for an Ontology of Engineering
}

This paper aims to sketch a critical historicisation of the empirical turn in the philosophy of technology. After presenting Achterhuis's definition of the empirical turn, I show how its final outcome is an ontophobic turn, i.e. a rejection of Heidegger's legacy. Such a rejection culminates in the Mr Wolfe Syndrome, the metamorphosis of the philosophy of technology into a positive science which, in turn, depends on an engineerisation/problematisation of reality, i.e. the eclipse of the difference between 'problem' and 'question'. My objection is that if Technology as such becomes nothing, then the paradoxical accomplishment of the empirical turn is the self-suppression of the philosophy of technology. As a countermovement, I propose an ontophilic turn, i.e. the establishment of a philosophy of technology in the nominative case whose first step consists in a Heidegger renaissance.

Keywords: philosophy of technology, empirical turn, Heidegger, engineering, postphenomenology

\section{Author Information}

Agostino Cera, Academy of Fine Arts of Naples https://orcid.org/0000-0002-4094-6066 https://accademiadinapoli.academia.edu/agostinocera

To Prof. Antonello Giugliano, In memoriam

How to cite this article:

Cera, Agostino. "Beyond the Empirical Turn: Elements for an Ontology of Engineering." Információs Társadalom XX, no. 4 (2020): 74-89.

$=$ https://dx.doi.org/10.22503/inftars.XX.2020.4.6

All materials

published in this journal are licenced

as CC-by-nc-nd 4.0 


\section{Introduction}

This paper aims to sketch a critical historicisation of the so-called empirical turn in the philosophy of technology. After introducing Achterhuis's definition of the empirical turn, namely the difference between a first and a second generation of philosophers of technology (Section 2), I present my critical historicisation according to which the final outcome of the empirical turn is an ontophobic turn, that is, a rejection of (overreaction against) Heidegger's legacy (Section 2). Such a rejection culminates in the Mr Wolfe Syndrome, that is, the transformation of the philosophy of technology into a problem-solving activity, or its epistemic metamorphosis into a positive science. Mr Wolfe Syndrome is itself the result of an engineerisation/problematisation of reality, namely the eclipse of the difference between 'problem' and 'question' (Section 4). By emphasising an aporia within Brey's apologetic reading of the empirical turn, I present the following objection to this state of things. If Technology (with a capital 'T') as such becomes nothing, then the philosophy of technology ceases to have a meaning in itself. As a result, the paradoxical accomplishment of the empirical turn should be the final self-suppression, or at least self-overcoming, of the philosophy of technology (Section 5). After quoting Volpi's claim about the risk of genetivisation for the philosophy of technology, I propose the idea of an ontophilic turn, namely the establishment of a philosophy of technology in the nominative case. The first step of this countermovement consists in a Heidegger renaissance, the concern of which is the safeguarding of both technology as philosophical question and the epistemic peculiarity (biodiversity) of philosophy itself. In fact, a philosophy of technology answers not only the question 'What is technology?' but also the question 'What is philosophy?' (Section 6).

\section{Towards the empirical turn}

In 1997 Hans Achterhuis - currently emeritus professor of systematic philosophy at the University of Twente - published as editor a collective volume which has become a reference point in the philosophy of technology: Van stoommachine tot cyborg; denken over techniek in de nieuwe wereld (Achterhuis 1997). This book represents the second part of a project started in 1992 with the publication of De maat van de techniek: Zes filosofen over techniek, Günther Anders, Jacques Ellul, Arnold Gehlen, Martin Heidegger, Hans Jonas en Lewis Mumford (Achterhuis 1992), where he dealt with "the "classical" founders of philosophy of technology' (Ihde 2001, vii). With this second stage, Achterhuis tried to give an overview of the post-Heideggerian and post-continental (i.e. American) philosophy of technology.

In 2001 an English (American) translation of the book was published with the title American Philosophy of Technology: The Empirical Turn (Achterhuis 
2001). This translation - found in the Indiana Series in the Philosophy of Technology of the Indiana University Press - is edited and prefaced by Don Ihde, general editor of this series and at present distinguished professor of philosophy at the Stony Brook University of New York. However, as is well-known, Ihde is first of all the fathers of the so-called postphenomenological approach, namely the current most influential approach in this area of study. ${ }^{1}$ His famous student Babette Babich defined him as 'arguably the preeminent American philosopher of technology' (Babich 2012-13, 46). Ihde's preface to this 'European perspective on contemporary American philosophy of technology' can therefore be considered a significant legitimation from the English-speaking philosophical milieu of Achterhuis's historical-hermeneutic reconstruction or, better, the acknowledgement that 'the centre of gravity for front-rank work in the philosophy of technology has probably shifted from Europe to North America' (Ihde 2001, vii - my italics).

Achterhuis argues that from the 1980s on, all philosophy of technology must be traced back to its empirical turn, namely to its rejection of the essentialist approach inspired by Heidegger (and, more in general, by continental philosophy). He defines Heidegger, Ellul, Arendt, Jonas and Mumford as 'the first-generation of philosophers of technology' or 'the classical philosophers of technology' (Achterhuis 2001,3). These 'founding fathers' dealt more with 'the historical and transcendental conditions that made modern technology possible than with the real changes accompanying the development of a technological culture' (Achterhuis 2001, 3). For both chronological and theoretical reasons, to this list must be added at least the names of Günther Anders - with his 'philosophical anthropology in the age of technocracy' (Anders 1992, 9) - and Arnold Gehlen - with his enquiry into 'the soul in the technological age' (Gehlen 1980), though both thinkers had already been taken into account in Achterhuis's 1992 book.

First generation

('Classical philosophers of technology')
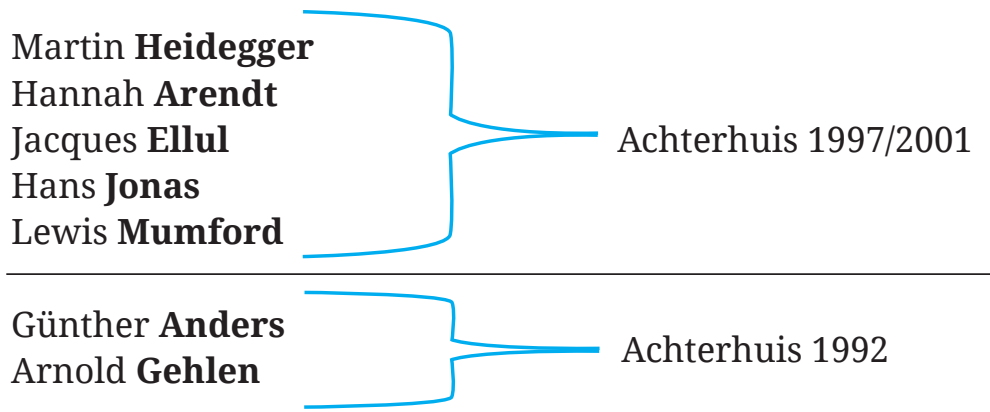

1 For an overview of postphenomenology see (Selinger 2006) and (Rosenberger and Verbeek 2015). 
As 'philosophical pioneers', the classical philosophers of technology understood that technology, as epochal phenomenon, represents the 'enjeu du siècle' (Ellul 1964). On the one hand, Achterhuis recognises that the first generation realized that technology is neither 'applied natural science' nor 'instrumentality' but rather 'form of life' that 'must be understood as a "system" (in Ellul's words) or as a "megamachine” (Mumford)' (Achterhuis 2001, 3). In his view, the efforts of the first generation to 'understand modern technology as "the other" of the symbolic-linguistic approach to reality, continue to guide the philosophy of technology' (Achterhuis 2001, 4). On the other hand, however, he believes that the founding fathers were unable to comprehend the manifold ways in which technology manifests itself' (Achterhuis 2001,3). More precisely, the limits of the first generation include essentialism, apriorism, determinism (one-dimensionalism) and dystopian attitude.

With reference to this topic, Philip Brey - who in 2010 proposed a first historicisation of the empirical turn - finds three basic criticisms against the first generation: 1) the image of technology portrayed by the classical approach 'was one-sidedly negative and pessimistic and showed little interest in positive aspects of technology'; 2) classical philosophy of technology tended to portray 'a deterministic image of modern technology as unstoppable and autonomous'; and 3) classical philosophy of technology was 'too general and abstract. In most studies, technology was studied in its entirety, as "Technology-with-a-capital-T"' (Brey 2010, 39 - my italics).

It is precisely from the awareness of these limits - namely from the observation that 'the time has come for an anti-essentialist philosophy of technology' (Feenberg 1999, 1) - that the empirical turn moves. It is characterised by a pragmatist, optimistic (or at least not apocalyptic), constructivist approach. According to Achterhuis, an important epistemic model of this turn is to be found in Thomas Kuhn's constructivist approach in the philosophy of science, which produces the idea of a natural co-evolution between technology and society (see Achterhuis 2001, 6). Manuel Castells, the Spanish sociologist and father of the 'network society', gives us a good explanation of the Kuhnean inspiration for the new approach to the question of technology. He affirms that 'we start from a rejection of technological determinism, as technology cannot be considered independently of its social context' (Castells 2004, xvii) and that 'the dilemma of technological determinism is probably a false problem, since technology is society, and society cannot be understood or represented without its technological tools' (Castells 2010, 5).

The empirical turn, namely the second generation of philosophers of technology, involves scholars such as Albert Borgmann (1984), author of the socalled device paradigm; Hubert Dreyfus (1992), a pioneer of 'the Critique of Artificial Reason'; Andrew Feenberg (1991), who studied with Herbert Marcuse and proposes a critical constructivism; Donna Haraway (1991), who deals with the question of technology in its link with feminism and posthumanism; the already mentioned Don Ihde (1993); and Langdon Winner (1980), 'the 
political theorist of technology' - as defined by Babette Babich (2012-13, 60). These authors are directly considered in Achterhuis's 2001 book, but various other scholars can be included within the empirical turn, such as Carl Mitcham (1994), considered by Achterhuis $(2001,4)$ 'the most important historian of the philosophy of technology'; Paul Durbin, another significant historian of the philosophy of technology (Durbin and Rapp 1983); Joseph Pitt (1995), a point of reference for the engineering-oriented philosophy of technology; David Noble (1997), a pioneer of studies about the religious meaning/power acquired by technology as epochal phenomenon; Thomas Hughes (1983) and Melvin Kranzberg (1985), the founders of the Society for the History of Technology; and Dutch scholar Peter-Paul Verbeek (2005), who in the last few years has been the primary follower of Ihde's postphenomenological approach on the continent. This means that 'empirical turn' is no longer a synonym for 'American philosophy of technology'.

\section{Second generation}

(Empirical turn)

Albert Borgmann (device paradigm)

Hubert Dreyfus (Critique of Artificial Reason)

Andrew Feenberg (critical constructivism)

Donna Haraway (techno-feminism)

Don Ihde (postphenomenology)

Langdon Winner (political philosophy of technology)

Carl Mitcham ('the most important historian of the philosophy of technology')

Paul T. Durbin (history of philosophy of technology)

Joseph C. Pitt (philosophy of technology and engineering)

Thomas Hughes and Melvin Kranzberg (history of technology)

David Noble (techno-theology)

Peter-Paul Verbeek (continental postphenomenology)

By commenting on the spirit of the empirical turn as expressed by Peter Kroes and Anthonie Meijers (2000), Franssen et al. (2016, 1) affirm that its claim was 'a reorientation of the community of philosophers of technology toward the practice of technology and, more specifically, the practice of engineering'.

According to Franssen et al. (2016), the very aim of the empirical turn is 'to steer the philosophical study of technology away from broad abstract reflections on technology as a general phenomenon toward addressing philosophi- 
cal problems that can be related directly to "the way technology works" or to "technology in the making". In doing so, it focused primarily on the work of engineers' (Franssen et al. 2016, 2). On this basis, Brey $(2010,40)$ believes that 'it is more proper to speak of two empirical turns: in the 1980s and 1990s two distinct approaches have emerged in response to the classical tradition, that both have been claimed to involve an empirical turn'. According to Brey, these two versions of the empirical turn are:

1) a 'first Empirical Turn', which can be considered its light version, a 'society-oriented approach in the philosophy of technology'; and

2) the 'other Empirical Turn', its hard version. 'The other empirical turn [...] is instead engineering-oriented' (Brey 2010, 40).

As Brey $(2010,40)$ explains, the first (society-oriented) empirical turn emerged in the 1980s and 1990s

when more and more philosophers working within the classical tradition were breaking free from some of its assumptions and methods. Neo-Heideggerians, neo-Critical Theorists and post-phenomenologists started to focus on concrete technologies and issues, attempted to develop contextual, less deterministic theories of technology or started borrowing them from STS, and started to assume a less dystopian, more pragmatic and balanced attitude towards modern technology.

Brey $(2010,40)$ identifies Andrew Feenberg, Don Ihde, Hubert Dreyfus and Donna Haraway as referent authors of this approach, as well as Larry Hickman, Andrew Light and Bruno Latour. In book form, the manifesto for such an approach is Achterhuis's American Philosophy of Technology: The Empirical Turn (2001).

The very aim of the second (engineering-oriented) empirical turn is 'to understand and evaluate the practices and products of engineering, rather than anything that happens beyond in society [...] Its primary aim is to understand and evaluate the practices and products of engineering, rather than anything that happens beyond in society.' This other empirical turn primarily took place in the 1990s and 2000s. It was also 'borne out of dissatisfaction with the classical approach, but the dissatisfaction was more radical' (Brey 2010, 40). Brey identifies Joseph Pitt, Peter Kroes and Anthonie Meijers as referent authors of this second approach, while 'important milestones in this new approach' (Brey 2010, 41) were New Directions in the Philosophy of Technology (Pitt 1995) and The Empirical Turn in the Philosophy of Technology (Kroes and Meijers 2000).

Finally, together with these two versions of the empirical turn ('resulting from an empirical turn within the field'), Brey finds a third approach, that is, the 'applied technology ethics' that emerges 'alongside the other two'. In his view, 'these three approaches now largely define the field' (Brey 2010, 42). 


\section{Brey's version of the empirical turn}

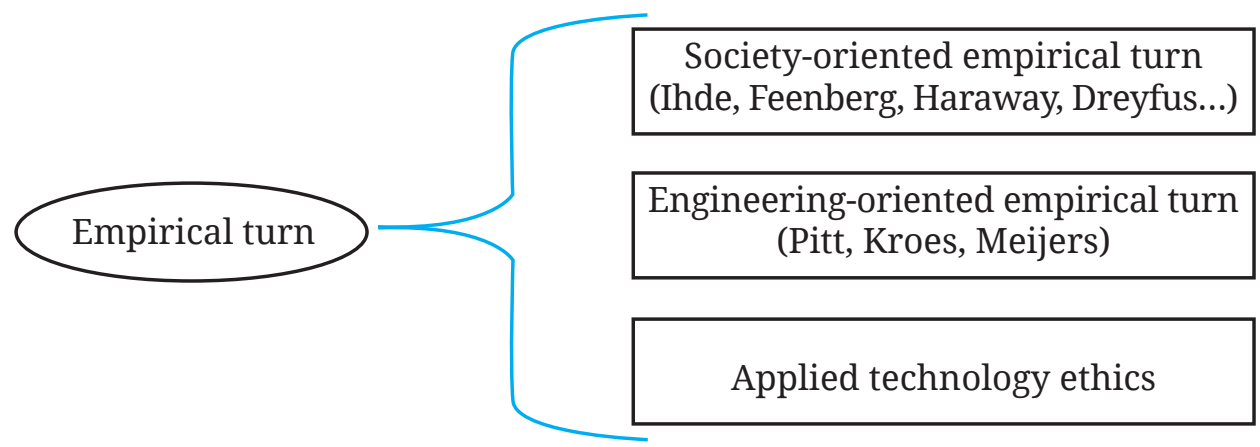

\section{Empirical turn as ontophobic turn}

What I am going to argue is that after 35 years - taking 1984 as a conventional birth date, namely the year in which Albert Borgmann's book Technology and the Character of Contemporary Life: A Philosophical Inquiry 2 was published - a first attempt at critical historicisation of such an experience is possible, and probably useful.

Such a statement needs to be justified, however, as by now there are many other works dealing with a historical evaluation of the empirical turn. Otherwise, as said, the peculiarity - and, hopefully, the usefulness - of my proposal has to do with its critical inspiration, namely its aim to deconstruct the empirical turn's narrative/discourse by calling into question some of its basic and unexpressed assumptions. In my opinion, the other historical overviews of this experience (Brey 2010; Franssen et al. 2016; ...), despite possessing indubitable qualities, are almost always characterised by an acritical attitude which turns them into historical apologies, namely confirmations that the empirical turn has been not only a good option (an improvement) for the philosophy of technology but its only possible option. In its essence, this kind of historicisation equates to a naturalisation of the empirical turn, which emerges in the end as a matter of fact or even a destiny.

With reference to my critical approach, my hermeneutic hypothesis is that during these 35 years the empirical turn has proven to be an ontophobic turn. By this expression I am suggesting an overreaction to the so-called essentialist approach to the question of technology, in particular a kind of rejection of Heidegger's legacy. I will immediately clarify this crucial point of my argument.

2 See Borgmann 1984. This book - and the figure of Borgmann, the 'German-American philosopher of technology', generally - represent a natural trait d'union between the continental/ Heideggerian tradition and the American philosophical milieu. On Borgmann's work see Tijmes (2001). 
The overreaction against Heidegger's legacy consists in a two-stage process. On one side we have the rejection (we could call it a legitimate rejection) of the potential 'mystical drift' involved in Heidegger's approach, namely his interpretation of technology as an Ereignis (event) within the history of Being. This mystical drift can be considered the pars construens (the affirmative side) of Heidegger's philosophy of technology expressed in the idea that 'technology is a way of revealing' (Heidegger 1977, 12). Such a legitimate rejection corresponds to a physiological parricide by the second generation of scholars, in order to free itself from a quite bulky - maybe too bulky - legacy.

However, on the other side this physiological parricide gradually turned into a total refutation: a real damnatio which involved the pars destruens (the deconstructive side) of Heidegger's approach as well. That is to say, a rejection of what - at least in my opinion - represents the basic epistemic assumption of the philosophy of technology itself, namely the condition of possibility for a properly philosophical approach to the question of technology. Such a pars destruens is expressed in another well-known Heideggerian sentence, according to which 'the essence of technology is by no means anything technological' (Heidegger 1977, 4). Melvin Kranzberg's first law of technology expresses this point (i.e. the inborn plurivocity/ambiguity of technology) even better by affirming that 'technology is neither good nor bad, nor is it neutral' (Kranzberg 1985, 50).

In my view, this second rejection should be considered an illegitimate rejection, that is, an overreaction from the second generation of scholars against Heidegger's legacy. Although one can find evidence for this overreactive tendency at every step of the empirical turn, I think it finds its fulfilment - its methodological implementation, so to say - in Ihde's postphenomenological approach.

\section{4. 'Mr Wolfe Syndrome', or engineering as worldview}

Concretely, this overreaction can be described as the transition from an over-distance to an over-proximity. That is to say, on the one side we have a disinterest in - or indifference towards - the ontic dimension (namely, the social, political and practical implications) of technology and therefore an over-distance. This attitude is typical of the first generation of philosophers of technology and can be epitomised by Heidegger's rejection of 'the instrumental and anthropological definition (Bestimmung) of technology' (Heidegger 1977, 5). This disinterest gradually turned into an almost exclusive interest in the same ontic dimension (and therefore an over-proximity), a movement typical of the second generation of philosophers of technology. The natural consequence of this attitude is an a priori disinterest in any ontological implication of technology, which is characterised ipso facto as 'essentialist' or 'deterministic' and thus ends up becoming a taboo. That is to say, a real onto-phobia.

The benchmark of this change of attitude in the philosophy of technology is the lexical replacement of its object: the transition from 'technology' (in the 
singular) to 'technologies' (in the plural). Not by chance, in his foreword to the English translation of Achterhuis's book, Don Ihde affirms that precisely this replacement of 'technology' with 'technologies in their relational and contextual implications' (Ihde 2001, viii) represents a distinguishing feature of the empirical turn.

I agree with the idea that such a replacement means much more than a lexical change, but in my view this semantic surplus corresponds to our increasing inability to acknowledge technology as something in itself/as such. In particular, I consider the main outcome of this replacement/inability to be what I call $\mathrm{Mr}$ Wolfe Syndrome. This formula is inspired by Harvey Keitel's famous character in Quentin Tarantino's movie Pulp Fiction (1994). This character presents himself as someone who 'solves problems'. By using this expression, I am therefore referring to the gradual transformation of the philosophy of technology into a problem-solving activity or, better, to the fact that philosophers of technologies are today becoming (or aspiring to become) 'guys who solve problems'. Charles Snow, in his famous 1959 report on the two cultures, in an attempt to describe the natural snobbery of the humanities against the sciences (i.e. of humanists/ men of letters against scientists/engineers) stated that 'intellectuals, in particular literary intellectuals, are natural Luddites' (Snow 2012, 22). Sixty years later, we must admit that those Luddites have turned into strikebreakers.

Mr Wolfe Syndrome embodies the effect of a further and deeper cause, that is, an epistemic metamorphosis of the philosophy of technology and, more generally, of philosophy itself. It is the attempt to definitively make it a 'positive Wissenschaft' (positive science), that is, a knowledge grounded on a 'positum': an absolute givenness, an epistemic and ontological dogma which can no longer be questioned. I mean 'positum', 'positive character' (Positivität) and 'positive science' according to their interpretation in Heidegger's essay Phenomenology and Theology ([1927] 1998): his epistemic manifesto. Here (Heidegger1998, 41), he gives the following epistemic-ontological definition of the positive sciences.

there are two basic possibilities of science: sciences of beings, of whatever is, or ontic sciences, and the science of being, the ontological science, philosophy. Ontic sciences in each case thematize a given being that in a certain manner is always already disclosed prior to scientific disclosure. We call the sciences of beings as given - of a positum - positive sciences.

On the contrary, he continues, 'ontology or the science of being [...] demands a fundamental shift of view: from beings to being'. As a consequence, 'within the circle of actual or possible science of beings - the positive sciences - there is between any two only a relative difference [...] On the other hand, every positive science is absolutely, not relatively, different from philosophy' (Heidegger 1998, 41). Given these assumptions, by Mr Wolfe Syndrome I mean the attempt to definitively make disappear, within the framework of the topic 'technology', the epistemic biodiversity of philosophy; to make it unrecognis- 
able, unperceivable. Or, if you prefer, to make us once and for all blind to this kind of difference.

In turn, both this epistemic metamorphosis and the consequent Mr Wolfe Syndrome can be considered the final results produced by the eclipse of the epistemic difference between 'problem' and 'question'. By 'problem' I mean that kind of interrogation which allows only solution as its possible answer. And by ‘solution' I mean that kind of answer which completely annihilates its own interrogation. That is to say, after reaching its solution, the interrogation in itself disappears, becomes nothing, ceases to make sense precisely because it is entirely solved. Problem is nothing but the premise (i.e. the occasion, the pretext) of a solution. On the other side, with 'question' (or better 'basic question' - I refer here to the German word Frage, or better Grund-Frage) I mean a kind of interrogation whose answer can be something different from a solution. A question is a potential unsolvable interrogation. Possible examples of these questions as unsolvable interrogations are two philosophical Grundfragen par excellence, that is, 'Why is there something, rather than nothing?' and 'What is called thinking?'. In the latter case, an 'adequate' answer (namely a pathic, non-logic, pre-logic answer) could be that philosophical keyword which Plato (Theaetetus, 155d) and Aristotle (Metaphysics I, 2, 982b) already suggested as the origin of thought: 'thaumazein'. Thaumazein represents a paradigmatic example of an answer without solution, that is, an answer which keeps its own interrogation alive, leaves it open. As a result, 'question' equates to an unsolvable but not meaningless interrogation.

On this basis, I believe that technology as philosophical issue (namely, as historical/epochal phenomenon) equates to such a Grundfrage. My worry is that, after 35 years, the empirical turn as ontophobic turn (i.e. overreaction against Heidegger's legacy) could entirely eclipse the epistemic difference between question and problem, and thus make any Grundfrage impossible. That is to say, it could make us insensitive, blind to any Grundfrage. In other words, if we firmly believe that any question must require/imply a solution (namely, that any question exists only insofar as it implies a solution, that any question must become a problem), then an unsolvable question (that is, a Grundfrage) becomes a non-question, namely a pseudo-problem, a pure mistake or misunderstanding. Translated as an ontological formula, this approach would read: 'What cannot be solved, is not.' As an imperative, it would read: 'Make everything solvable.'; 'Make a problem of everything.' Solveability therefore emerges as an epochal passepartout, the current basic ontological feature of any entity.

Now, insofar as the problem-solving logic represents the conceptual dispositive of the engineering approach, I call such an attempt to eclipse the epistemic difference between problem and question engineerisation. The ultimate goal of this engineerisation is to achieve a complete problematisation of reality, that is, to build an epistemic and ontological framework within which 'problem' becomes the only possible way of interrogation. On this ba- 
sis, the 'question concerning technology', as Grundfrage, is bound to become a non-question, a nonsense. It is not by chance therefore that Brey and the other apologetic historians of the empirical turn identify its peculiarity precisely with the definitive approximation of the philosophy of technology to engineering. In particular, according to Brey $(2010,40)$, the engineering-oriented empirical turn represents the authentic empirical turn, its natural and necessary outcome. That is to say, its entelechy.

\section{A requiem for the philosophy of technology?}

With reference to this whole state of things I have described, my objection is the following. If Technology (with a capital ' $\mathrm{T}$ ') as such, that is, technology as potential Weltanschauung or grand récit of our age, as current 'subject of history' (Anders 1992, 271-9) ... well, if technology as such is/becomes nothing (if it comes to represent at most the umbrella term or the summation of the single technologies), then the paradoxical but entirely consequential result of this situation is that the philosophy of technology ceases to have a meaning and a value in itself. In other words, if the philosophy of technology turns entirely into a problem-solving activity (into a search for solutions in front of the concrete problems emerging from the single technologies), then it must be admitted that this kind of activity can be performed much better by 'experts' (scientists, engineers, politicians ...) than by philosophers.

As a consequence, the ontophobic turn in philosophy of technology (namely, the overreaction against Heidegger's legacy) culminates in the disappearance of the reason itself for a strictly philosophical approach to the question of technology. Given this assumption, the paradoxical accomplishment/fulfilment of the empirical turn should be the final self-suppression, or at least self-overcoming, of the philosophy of technology.

This objection also gives me the opportunity to emphasise a significant aporia within Brey's argument and more generally within the discourse of the apologetic historians of the empirical turn. Dealing with the 'Limitations of Contemporary Philosophy of Technology' (the premise for establishing an 'Agenda for the Philosophy of Technology'), Brey focuses on three questions which he considers the 'major questions' for the philosophy of technology. They are: 1) 'What is technology?'; 2) 'How can the consequences of technology for society and the human condition be understood and evaluated?'; and 3) 'How should we act in relation to technology?' (Brey 2010, 43 - my italics). The first question is 'the central concern of engineering-oriented philosophy of technology', the second question is 'the province of society-oriented philosophy of technology, but also of technology ethics', while the third is 'wholly the concern of technology ethics' (Brey 2010, 43). Brey affirms that only the engineering-oriented philosophy of technology is able to carry out its task, that is, to answer (solve) its own question (problem), while in their current versions the society-oriented philosophy of technology 
and the technology ethics 'are not sufficiently equipped to provide full and cogent answers to the second and third research question[s]' (Brey 2010, 43).

In my view, the basic aporia of this position is that Brey presumes to answer a question/solve a problem - 'What is technology?' - which he himself (through his approach to the question of technology) has made meaningless. More clearly, my point is: how can answering the question concerning the ontological status, or even the essence, of technology (in the singular, as something in itself) be the same approach which characterises itself by establishing the definitive overcoming of 'Technology-with-a-capital-T'? That is to say, by establishing the definitive overcoming of the ontological question itself? The only possible escamotage I can find for this aporia has to do with the formulation of the question, that is, the interpretation of its meaning. The engineering-oriented approach - which in turn represents the quintessence of the empirical turn - can answer the question 'What is technology?' only because, according to its assumptions, 'What is?' ipso facto means 'How does it work?'. As a result, the ontological question 'What is technology?' turns into the concrete problem 'How does (a single) technology work?' and thus immediately becomes something solvable, that is, the only legitimate/real interrogation for this approach. It is a paradigmatic example of empirical turn as ontophobic turn, because this reformulation/translation of the question 'What is technology?' is entirely based on a negation/annihilation of the ontological level.

This ontophobic escamotage is the attempt to annihilate the epistemic peculiarity of the philosophy of technology (and of philosophy in general) by definitively transforming it into a positive Wissenschaft or, better, a problem-solving activity; that is to say, by identifying - (con)fusing - philosophy with engineering. Brey's aporia, particularly in its engineering-oriented version, unintentionally confirms that the empirical turn's only possible answer to the question 'What is technology?' is 'Technology (i.e. in itself/as such) is nothing.'.

\section{Ontophobic turn}

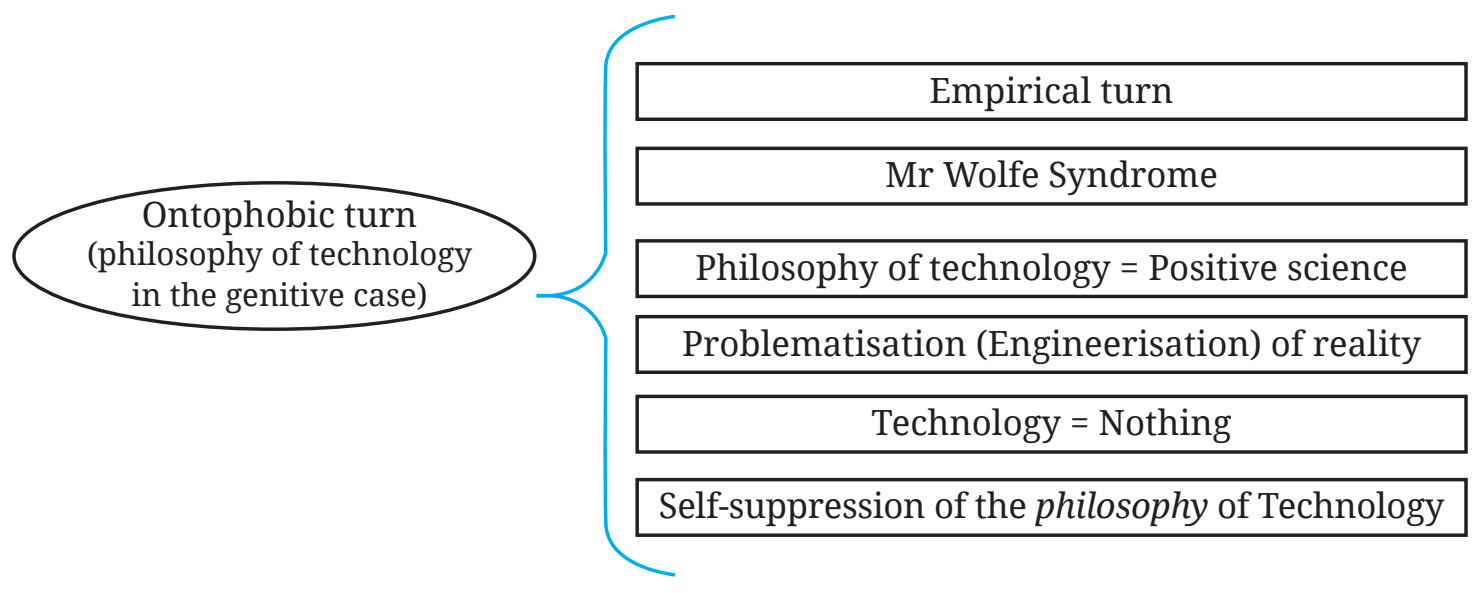




\section{The ontophilic turn: Towards a philosophy of technology in the nominative case}

Before concluding, I would like to quote some lines from Franco Volpi that represent a perfect synthesis of my point, an important source of inspiration for the pars construens of my work on the philosophy of technology. In his book on nihilism, Volpi speaks about the risk of genetivisation for philosophy today, in particular for the philosophy of technology. He affirms:

There is a risk: that yet another philosophy in the genitive case will be produced. I mean, a reflection whose only function is ancillary and subordinate [... T] $]$ he risk of numerous genitive philosophies is to reduce philosophical thought to a noble anabasis, namely to a strategic withdrawn from the great questions to take refuge in problems of detail [...] So, one asks oneself: is philosophy of technology in the nominative case (filosofia della tecnica al nominativo) possible? (Volpi 2004, 146-7).

On the basis of the arguments I sketched in this paper, I think that such a genetivisation is already underway, and that it corresponds to the ontophobic outcome characterising the current mainstream in the philosophy of technology, that is, the attempt to overcome/annihilate its epistemic peculiarity by transforming it into a positive Wissenschaft, or problem-solving activity. Given this assumption, in my view the most urgent work needed in this field is an attempt to give an affirmative reply to Volpi's question (a philosophy of technology in the nominative case is possible)3 by means of a countermovement (in the sense of Nietzsche) towards the currently prevailing ontophobic turn.

The first step of an ontophilic turn consists in the right metabolisation of Heidegger's legacy. In other words, the foundation of a philosophy of technology in the nominative case must involve a Heidegger renaissance or a 'going back to being fair with Heidegger'. This means that we must avoid the potential mystical drift of his approach without compromising the epistemic imprimatur he gave to this area of study. What is truly at stake in this Heidegger renaissance is both the safeguarding of the Fragwürdigkeit (questionworthiness) of technology for philosophical thought and the epistemic peculiarity/ biodiversity of philosophy itself, since a philosophy of technology answers not

\footnotetext{
3 For several years I have been working on my personal interpretation of such a philosophy of technology. I call it 'Philosophy of Technology in the Nominative Case (TECNOM)' and have presented it in various papers, for example Cera 2017 and 2018, 131-80. I would like to mention two of the many heterodox examples of such a countermovement against the current mainstream in the philosophy of technology: 1) Babette Babich who, as Ihde's student, criticises postphenomenology's overreaction against the classical philosophy of technology; and 2) the 'Wageningen-Nijmegen Group' (Vincent Blok, Pieter Lemmens and Jochem Zwier) which claims a 'terrestrial turn in philosophy of technology' (see Lemmens, Blok and Zwier 2017).
} 
only the question 'What is technology?' but also - and maybe even more so the question 'What is philosophy?'. At the basis of any philosophical interpretation of technology lies an interpretation of philosophy.

If technology as such/in itself is something, in particular if it - as epochal phenomenon - equates to the current subject of history, then the philosophy of technology will also emerge as the current version of the philosophy of history. Or, better, it will emerge as our best resource for doing in the here and now what philosophy has always tried to do: to 'comprehend its own time in thoughts' (Hegel 1991, 21).

At this point it should be clear that the countermovement I am proposing (i.e. ontophilic turn or philosophy of technology in the nominative case) consists of a re-philosophising of the philosophy of technology; that is, a philosophical (re)turn in the philosophy of technology.

As a conclusion, I would like to quote the wise words that Albert Borgmann shared with me during a private conversation on these topics (as is well-known, Borgmann is one of the protagonists of the empirical turn, a key figure in the transition from the first to the second generation of philosophers of technology). I think they represent the real spirit of my proposal, which wants to be not an ordeal - that is, a fanatic pro or contra Heidegger - but an attempt to preserve the irreplaceability of a strictly philosophical approach to the question of technology. My proposal's very aim is 'only' to keep the difference between question (Grundfrage) and problem alive, to keep our sensibility towards such a nuance alive. In fact, 'by honoring this questionworthiness (Fragwürdigkeit), philosophy possesses its own dignity, one that cannot be derived from elsewhere and cannot be calculated' (Heidegger 2012, 7).

Borgmann affirms:

I agree that the Grundfrage is the source of the deepest insights and that we should not let it get buried by a problem-oriented approach. There are Sundays in philosophy, when we festively celebrate insight. But there is also the week-day philosophy, when we busy ourselves with problems. As long as problem-solving does not obliterate the Grundfrage, we should allow for a space for it.

\section{References}

Achterhuis, Hans, (ed.). De maat van de techniek: Zes filosofen over techniek, Günther Anders, Jacques Ellul, Arnold Gehlen, Martin Heidegger, Hans Jonas en Lewis Mumford. Ambo: Baarn \& Schoten, 1992.

Achterhuis, Hans (ed.). Van stoommachine tot cyborg; denken over techniek in de nieuwe wereld. Amsterdam: Uitdigeverij Ambo, 1997. 
Achterhuis, Hans (ed.). American Philosophy of Technology: the Empirical Turn (The Indiana Series in the Philosophy of Technology), trans. R. P. Crease. Bloomington/Indianapolis: Indiana University Press, 2001.

Anders, Günther. Die Antiquiertheit des Menschen 2. Über die Zerstörung des Lebens im Zeitalter der dritten industriellen Revolution. München: Beck, 1992.

Babich, Babette. "O, Superman! Or Being towards Transhumanism: Martin Heidegger, Günther Anders, and Media Aesthetics.” Divinatio XXXVI (2012-2013): 41-99.

Borgmann, Albert. Technology and the Character of Contemporary Life: A Philosophical Inquiry. Chicago: University of Chicago Press, 1984.

Brey, Philip. "Philosophy of Technology after the Empirical Turn.” Techné: Research in Philosophy and Technology 14, no. 1 (2010): 36-48. https://doi.org/10.5840/techne20101416.

Castells, Manuel (ed.). The Network Society: A Cross-cultural Perspective. Cheltenham (UK), Northampton (MA): Edward Elgar, 2004.

Castells, Manuel. The Rise of the Network Society (The Information Age: Economy, Society and Culture Vol. I). Malden (MA), Oxford (UK): Wiley-Blackwell, 2010.

Cera, Agostino. “The Technocene or Technology as (Neo)environment.” Techné: Research in Philosophy and Technology 21, no. $2 / 3$ (2017): 243-81. https://doi.org/10.5840/techne201710472.

Cera, Agostino. Der Mensch zwischen kosmologischer Differenz und Neo-Umweltlichkeit. Über die Möglichkeit einer philosophischen Anthropologie heute. Nordhausen: Verlag Traugott Bautz, 2018.

Dreyfus, Hubert. What Computers Still Can’t Do: A Critique of Artificial Reason. Cambridge (Mass.): MIT Press, 1992.

Durbin, Paul and Friederich Rapp (eds.). Philosophy and Technology (Boston Studies in the Philosophy of Science vol. 80). Dodrecht and Boston: D. Reidel Publishing Company, 1983.

Ellul, Jacques. The Technological Society, trans. J. Wilkinson, New York: Vintage Books, 1964.

Feenberg, Andrew. Critical Theory of Technology. Oxford: Oxford University Press, 1991.

Feenberg, Andrew. Questioning Technology. London/New York: Routledge, 1999.

Franssen, Maarten and Pieter E. Vermaas and Peter Kroes and Anthonie W.M. Meijers (eds.). Philosophy of Technology after the Empirical Turn (Philosophy of Engineering and Technology vol. 23). Cham: Springer International, 2016.

Gehlen, Arnold. Man in the Age of Technology, trans. C. McMillan and K. Pillemer. New York: Columbia University Press, 1980.

Haraway, Donna. Simians, Cyborgs and Women: The Reinvention of Nature. New York: Routledge, 1991.

Hegel, Georg Wilhelm Friedrich. Elements of the Philosophy of Right, trans. H. B. Nisbet. Cambridge and New York: Cambridge University Press, 1991.

Heidegger, Martin. “The Question Concerning Technology.” In The Question Concerning Technology and Other Essays, trans. W. Lovitt, 3-35. New York \& London: Garland, 1977.

Heidegger, Martin. "Phenomenology and Theology.” In Pathmarks, trans. W. McNeill, 39-62. Cambridge \& New York: Cambridge University Press, 1998.

Heidegger, Martin. Contribution to Philosophy (Of the Event), trans. R. Rojcewicz and D. Vallega-Neu. Bloomington/Indianapolis: Indiana University Press, 2012.

Hughes, Thomas P. Networks of Power: Electrification in Western Society, 1880-1930. Baltimore: Johns Hopkins University Press, 1983. 
Ihde, Don. Postphenomenology: Essays in the Postmodern Context. Evanston (Ill.): Northwestern University Press, 1993.

Ihde, Don. "Foreword.” In Achterhuis 2001: vii-ix.

Kranzberg, Melvin. “The information Age: Evolution or Revolution?” In Information Technologies and Social Transformation, edited by Bruce R. Guile, 35-53. Washington (DC): National Academy Press, 1985.

Kroes, Peter and Anthonie Meijers (eds.). The Empirical Turn in the Philosophy of Technology. Amsterdam: JAI-Elsevier, 2000.

Lemmens, Pieter and Vincent Blok and Jochem Zwier. "Toward a Terrestrial Turn in Philosophy of Technology.” Techné: Research in Philosophy and Technology 21, no. 2/3 (2017): 114-26. https://doi.org/10.5840/techne2017212/363.

Mitcham, Carl. Thinking through technology: The path between engineering and philosophy. Chicago: University of Chicago Press, 1994.

Noble, David. F. The Religion of Technology; The Divinity of Man and the Spirit of Invention. New York: Knopf, 1997.

Pitt, Joseph T. (Ed.). New Directions in the Philosophy of Technology (Philosophy and Technology vol. 11). Dodrecht: Springer, 1995.

Rosenberger, Robert and Peter-Paul Verbeek (eds.). Postphenomenological Investigations: Essays on Human-Technology Relations. Lanham (MD): Lexington Books, 2015.

Selinger, Evan (Ed.). Postphenomenology: A Critical Companion to Ihde. Albany: State University of New York Press, 2006.

Snow, Charles P. The Two Cultures. Cambridge and New York: Cambridge University Press, 2012.

Tijmes, Pieter. “Albert Borgmann: Technology and the Character of Everyday Life.” In Achterhuis 2001: 11-36.

Verbeek, Peter-Paul. What Things Do: Philosophical Reflections on Technology, Agency, and Design. Penn State: Penn State University Press, 2005.

Volpi, Franco. Il nichilismo. Roma-Bari: Laterza, 2004.

Winner, Langdon. “Do Artifacts Have Politics?” Daedalus 109, no. 1 (1980): 121-36. 